\title{
Adhesion to and invasion of human colon carcinoma Caco- 2 cells by Aeromonas strains
}

\author{
Y. NISHIKAWA, A. HASE, J. OGAWASARA, S. M. SCOTLAND*, H. R. SMITH* and T. KIMURA \\ Department of Epidemiology, Osaka City Institute of Public Health and Environmental Sciences, Tennoji, Osaka 543, \\ Japan and * Laboratory of Enteric Pathogens, Central Public Health Laboratory, 61 Colindale Avenue, London NW9 \\ $5 H T$
}

\begin{abstract}
Summary. The enteropathogenicity of Aeromonas strains that showed mannose-resistant adhesion to INT 407 cells was evaluated by infecting Caco- 2 cells and observing them by light and electronmicroscopy. Five of six strains adhered in large numbers to Caco-2 cells in the presence of mannose and caused cytopathic effects. Two strains of Aeromonas spp. seemed to invade Caco-2 cells, as membrane-bound bacteria were seen within the cytoplasm of these cells; however, staining by acridine orange-crystal violet appeared to show intracellular fluorescent bacteria in three strains. Fimbriae did not appear to play an important role in adhesion because fimbrial structures were not seen by transmission electronmicroscopy. Adhesion of four strains was inhibited by the addition of L-fucose. The strains were negative in the fluorescence actin staining test, which in enteropathogenic Escherichia coli strains correlates with the ability to attach and efface intestinal microvilli. The DNA of the Aeromonas strains did not hybridise with the $E$. coli eae and ipa $\mathrm{B}$ probes, associated with attaching and effacing ability and invasion, respectively. These results give support to the enteropathogenicity of adhesive strains of Aeromonas spp., although the mechanisms of adhesion, and possibly invasion, remain to be elucidated.
\end{abstract}

\section{Introduction}

Aeromonas organisms have been recognised as causal agents of human gastrointestinal disease. ${ }^{1-3}$ However, the organisms are autochthonous inhabitants of aquatic environments and are isolated frequently from various foods and environmental specimens. ${ }^{4-6}$ It is not known whether all such strains are pathogenic.

Most strains of Escherichia coli are non-pathogenic in the intestine, although some can produce diarrhoea by a number of distinct mechanisms. ${ }^{7,8}$ Most aeromonads might similarly be non-pathogenic in the intestine and only some strains possess virulence factors. Methods for discrimination between isolates of Aeromonas spp. that are pathogenic for man, and those from the environment that may be non-pathogenic, are clearly required. Although $\beta$-haemolysin production might seem to be a likely pathogenic factor of Aeromonas spp., ${ }^{9,10}$ the failure of haemolytic strains to cause diarrhoea in human volunteers suggests that haemolysin per se is not the sole determinant of virulence. ${ }^{11}$

Adhesion of bacteria to mucosal surfaces has been recognised as an important step in the pathogenesis of most infections in man and animals. Enterotoxigenic E. coli (ETEC) and Vibrio cholerae induce diarrhoea

Received 5 May 1993; accepted 29 June 1993. by elaboration of enterotoxin after adhesion to the intestinal mucosa. ${ }^{12}$ Both adhesins and enterotoxins were necessary for production of diarrhoea in volunteers fed orally with ETEC. ${ }^{13}$ Although most strains of $A$. hydrophila and $A$. sobria produce $\beta$-haemolysin as a possible enterotoxin, few strains may possess adhesins. ${ }^{5}$

Recently, we found that aeromonads that were adhesive to INT407 cells in the presence of mannose were present at significantly higher levels among strains isolated from faeces than among strains isolated from samples of food and river water. ${ }^{14}$ These findings suggest that mannose-resistant adhesion may be important for infection by aeromonads. However, volunteer experiments would be needed to prove this.

The Caco-2 cell line, which was derived from a carcinoma of the colon, exhibits the morphological and functional characteristics of normal small intestinal cells in post-confluent culture. ${ }^{15} \mathrm{Caco}-2$ cells are being recognised as a substitute for human intestinal epithelial cells and are used to study the adhesion and invasion of enteric pathogens. ${ }^{16-21}$ Panigrahi et al. ${ }^{22}$ showed that the adhesion of non-O1 $V$. cholerae to Caco-2 cells correlated with human intestinal colonisation or disease occurrence or both.

In this study, to assess the enteropathogenicity of aeromonads that had shown mannose-resistant adhesion to INT407 cells, Caco-2 cells were infected with the organisms and cytopathogenic effects were ob- 
served by scanning and transmission electronmicroscopy. In some experiments, Caco-2 cell cultures of different age were compared since cell differentiation is growth related $;{ }^{15}$ adhesion of ETEC and the expression of receptors for diffusely adhering $E$. coli has been reported to be dependent on the differentiation of Caco-2 cells. ${ }^{16,19}$ In addition, the strains were examined by DNA probing for the presence of genes homologous to the $E$. coli attaching and effacing gene $e a e$ and the invasion gene ipaB. ${ }^{23,24}$

\section{Materials and methods}

\section{Bacteria}

Four A. hydrophila strains (nos. 22, 62, 107 and 189) and two $A$. sobria strains (nos. 21 and 106) were used. These strains were isolated originally from human faeces, ${ }^{5}$ and had shown marked mannose-resistant adherence to INT407 cells. ${ }^{14}$ An enteroinvasive $E$. coli strain (E35990, O143:H-) was used as a positive control in ipa $\mathrm{B}$ hybridisation tests and in studies of cell invasion. An enteropathogenic E. coli strain (E2347/ 69, O127:H6) was used as a positive control in eae hybridisation tests.

\section{Epithelial cells}

Caco-2 cells were obtained from the American Type Culture Collection (ATCC; HTB37) and cultured according to the method of Finlay and Falkow. ${ }^{18}$ Cells were grown in Eagle's Minimal Essential Medium (EMEM) (Nissui Pharmaceutical Co., Tokyo, Japan) with Earle's salts and $2 \mathrm{~mm}$ glutamine, supplemented with fetal bovine serum $10 \%$ and sodium pyruvate (Flow Laboratories, Irvine) $1 \%$ without antibiotics. Transwell filter units (3415; Costar, Cambridge, MA, USA) containing a $0.33-\mathrm{cm}^{2}$ porous filter membrane (3.0- $\mu \mathrm{m}$ pores) and eight-chambered tissue culture slides (Nunc, Naperville, IL, USA) were used to culture Caco-2 cells for the infection experiments for electronmicroscopy and light microscopy, respectively. A trypsinised Caco- 2 cell suspension $(250 \mu \mathrm{l})$ in tissue culture medium was added apically to each transwell unit or to each chamber of the chambered slides. The transwell unit was placed in a well containing $0.5 \mathrm{ml}$ of fresh medium, in a 24-well tissue culture plate. Tissue culture medium was changed twice weekly, and monolayers were used after incubation for $>14$ days $\left(37^{\circ} \mathrm{C}, \mathrm{CO}_{2} 5 \%\right)$ unless otherwise stated. In some experiments, 5-day-old cultures of Caco-2 cells were used for comparison.

\section{Tissue culture adhesion}

Adherence tests were performed as described previously. ${ }^{14}$ To prepare inocula, the strains were seeded into nutrient broth and incubated statically for $18 \mathrm{~h}$ at $30^{\circ} \mathrm{C}$. A 200 -fold dilution of each culture was made in EMEM supplemented with D-mannose $1 \%, 2 \mathrm{~mm}$ glutamine and fetal calf serum $2 \%$, and used as inoculum; it contained c. $5 \times 10^{6} \mathrm{cfu} / \mathrm{ml}$. In some experiments, L-fucose $1 \%$ or D-galactose $1 \%$ replaced D-mannose. A $250-\mu \mathrm{l}$ portion of each inoculum was introduced into each chamber or transwell unit and incubated for $30 \mathrm{~min}$ at $37^{\circ} \mathrm{C}$ (the infection period). Unattached bacteria were then removed from the monolayer by three washings in situ each with $250 \mu$ lof Hanks's Balanced Salts Solution. Then $250 \mu \mathrm{l}$ of EMEM supplemented with fetal calf serum $2 \%$ and Dmannose $1 \%$ or $\mathrm{L}$-fucose or D-galactose was added to each chamber. After incubation for 1,2 or $3 \mathrm{~h}$ at $37^{\circ} \mathrm{C}$ (the multiplication period), the monolayers were washed four times, each time with $250 \mu$ l of Hanks's Balanced Salts Solution. The cells on chamber slides were then fixed with methyl alcohol for $5 \mathrm{~min}$ and stained for 20 min with Giemsa $10 \%$ for light microscopy.

\section{Actin accumulation tests}

The fluorescence actin staining test (FAS test) was performed as described previously. ${ }^{25}$ Briefly, Caco-2 cells were fixed with formaldehyde $3 \%$ at the end of an adhesion test. Cells were rendered permeable with Triton X100 $0 \cdot 1 \% \mathrm{v} / \mathrm{v}$ in phosphate-buffered saline (PBS), treated with fluorescein isothiocyanatephalloidin (Sigma) $5 \mu \mathrm{g} / \mathrm{ml}$ in PBS and examined for the presence of fluorescing accumulations of filamentous actin beneath attached bacteria by consecutive incident light fluorescence and phase-contrast microscopy of the same microscopic fields.

\section{Electronmicroscopy}

For electronmicroscopy, Caco-2 cells on transwell units were fixed in phosphate-buffered glutaraldehyde $1 \%$ at $4^{\circ} \mathrm{C}$. Some samples for transmission electronmicroscopy were fixed in phosphate-buffered glutaraldehyde $1 \%$ containing ruthenium red $0.075 \%$. For scanning electronmicroscopy, fixed cells were dehydrated in ascending concentrations of ethanol (25$100 \%$ ), and critical point dried in liquid $\mathrm{CO}_{2}$. Specimens were mounted on stubs with silver paint, sputter coated with gold palladium, and examined with a Jeol scanning electronmicroscope (JSM-5300). For transmission electronmicroscopy, samples were post-fixed in cold $\mathrm{OsO}_{4} 1 \%$ in $0 \cdot 1 \mathrm{M}$ phosphate buffer, $\mathrm{pH} 7 \cdot 3$, for $2 \mathrm{~h}$ and then stained with saturated uranyl acetate overnight. Samples were dehydrated in a series of increasing amounts of ethanol and embedded in epoxy resin, then sectioned and stained with lead citrate before examination in a Jeol electronmicroscope (JEM-1200 EXII).

\section{Staining of intracellular bacteria}

Acridine orange-crystal violet staining was performed to detect specifically intracellular bacteria by a modification of the method of Miliotis. ${ }^{26}$ After the 

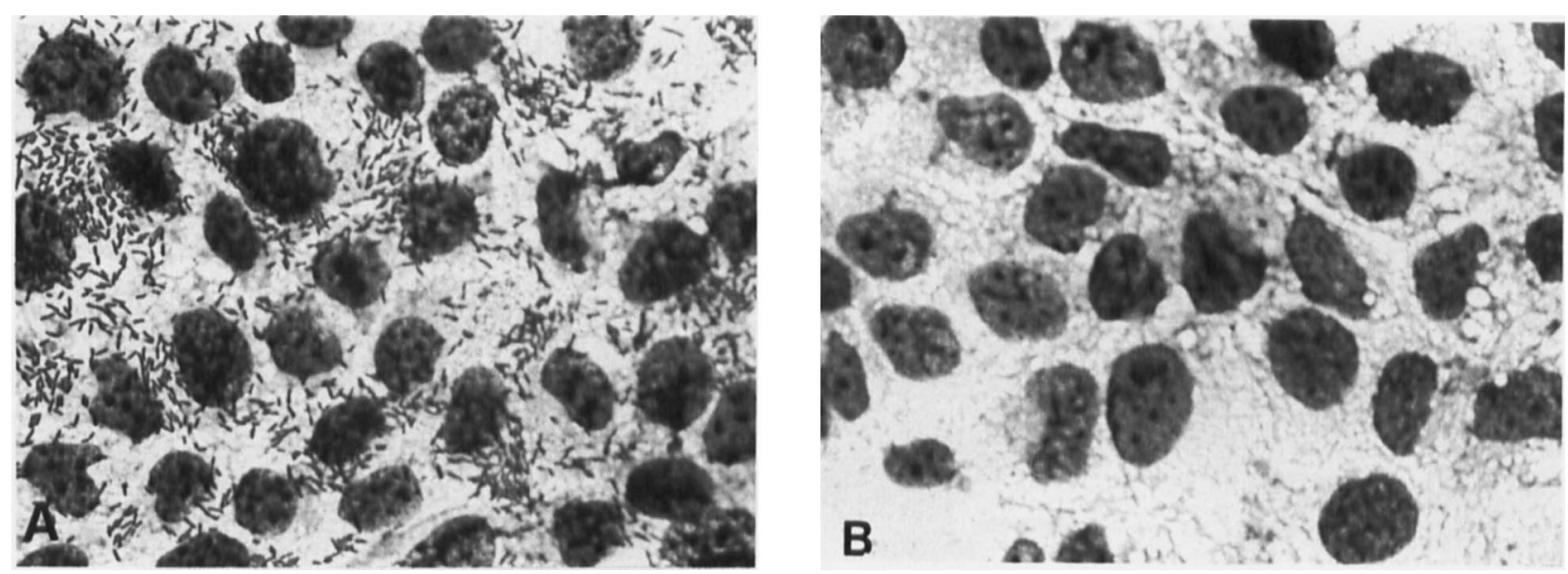

Fig. 1. Light micrographs of Caco-2 cells infected by $A$. hydrophila (strain no. 189). A, massive diffuse adhesion can be seen on the cells; $\mathbf{B}$, no adhesion is visible in the presence of $\mathrm{L}$-fucose. $(\times 575)$.
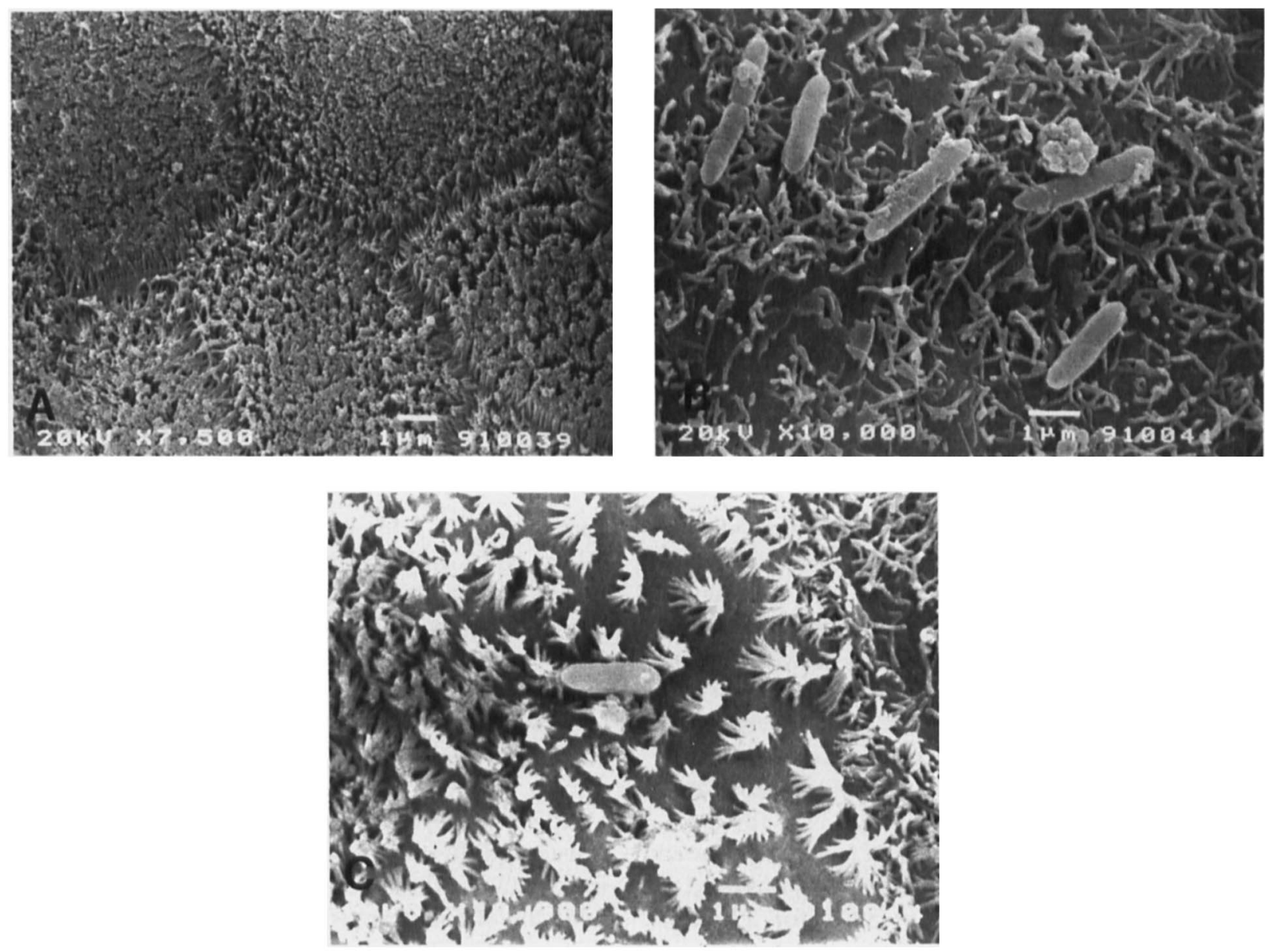

Fig. 2. Scanning electronmicrographs of Caco-2 monolayers infected by $A$. sobria (strain no. 106). A, uninfected monolayer with well-defined brush borders; $\mathbf{B}$, Caco- 2 cells in early stages of infection, aeromonads interacting with decreased microvilli; $\mathbf{C}$, irregularities in the distribution of microvilli can be seen. Bar $=1 \mu \mathrm{m}$.

tissue culture adhesion test, Caco-2 cells were stained with acridine orange $0.01 \%$ in Earle's Balanced Salts Solution (Flow Laboratories, Irvine) for $45 \mathrm{~s}$, and counter-stained with crystal violet $0.05 \%$ in physiological saline solution for $30 \mathrm{~min}$. Although crystal violet was reported ${ }^{26}$ to quench the fluorescence of $E$. coli in $45 \mathrm{~s}$, it took $30 \mathrm{~min}$ for Aeromonas spp. to do so. After the cells were rinsed with Earle's salts solution, slides were viewed under a fluorescence microscope. All infecting bacteria take up the acridine orange and fluoresce; only intracellular bacteria should be resistant to quenching with crystal violet and remain visible by fluorescent light microscopy.

\section{DNA hybridisation tests}

The presence of DNA sequences associated with attaching and effacing lesions was detected with a $1-\mathrm{kb}$ KpnI-SalI fragment, the eae probe. ${ }^{23}$ The probe for invasion sequences was a $1-\mathrm{kb} E c o$ RI-Sall fragment 

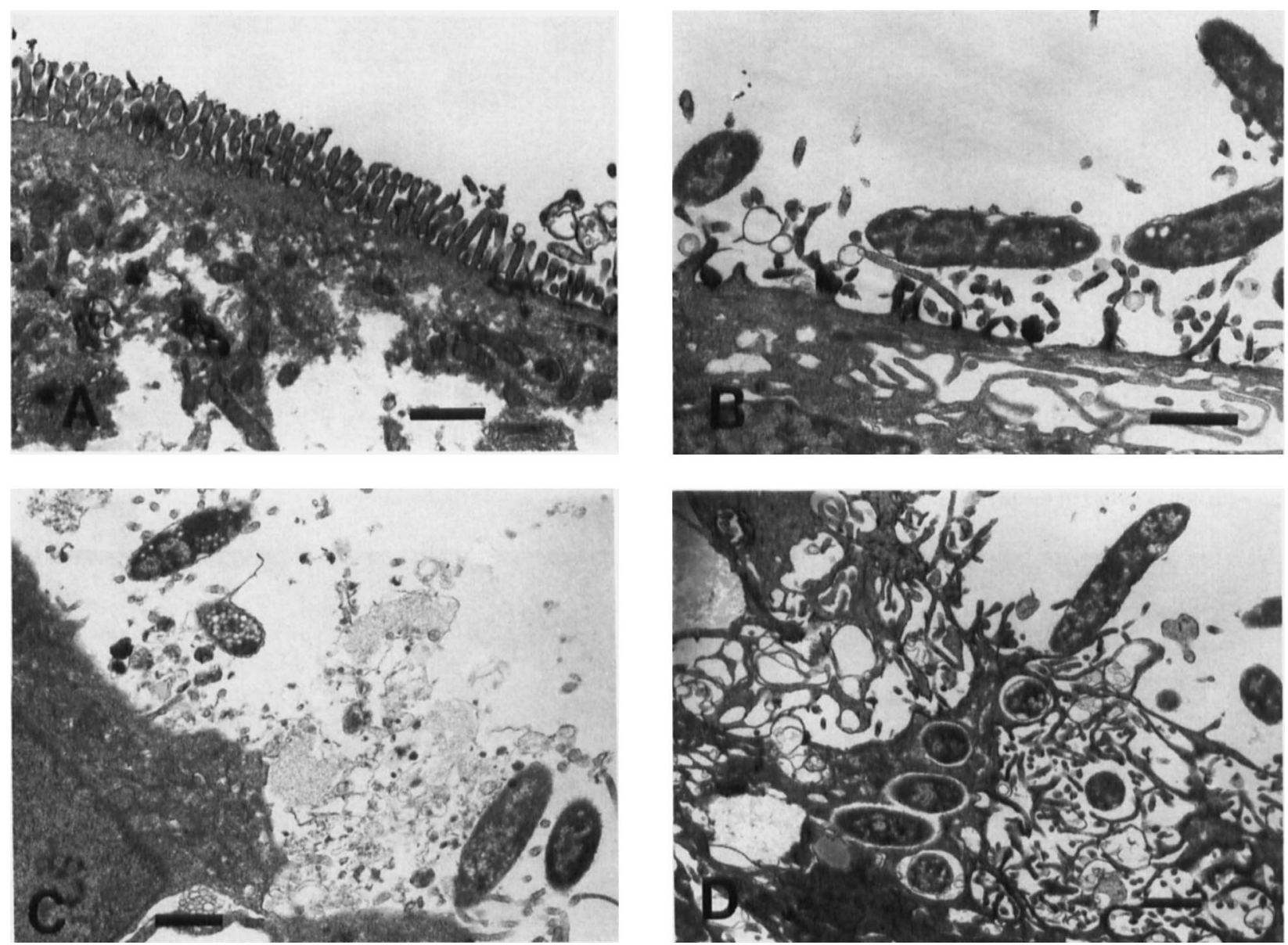

Fig. 3. Transmission electronmicrographs of Caco-2 monolayers infected by A. hydrophila (strain no. 62). A, uninfected cell showing well developed microvilli; $\mathbf{B}$, aeromonads adhering to microvilli; $\mathbf{C}$, the grossly damaged microvillous cell surface; $\mathbf{D}$, bacteria enclosed within membrane-bound vacuole inside Caco-2 cell; a bacterium is likely to be in direct contact with cell cytoplasm. Bar $=1 \mu \mathrm{m}$.

derived from plasmid $\mathrm{H} 1$ and was kindly provided by Dr Sansonetti, Institut Pasteur. ${ }^{24}$ Restriction fragments for probes were excised under long wavelength UV from preparative agarose gels. The gel slice was boiled and the DNA was labelled with deoxyadenosine $5^{\prime}-\alpha-\left[{ }^{35} S\right]$-thiotriphosphate by the random primer method. ${ }^{27}$ Aeromonas strains were grown overnight at $37^{\circ} \mathrm{C}$ in nutrient broth. Broth cultures were spotted on to nylon membranes (Hybond N, Amersham) placed on nutrient agar plates, and grown at $37^{\circ} \mathrm{C}$ for $c .6 \mathrm{~h}$. Bacteria were lysed and their DNA was denatured according to the standard method. ${ }^{28}$ DNA was fixed to the nylon matrix by baking at $80^{\circ} \mathrm{C}$ for $2 \mathrm{~h}$. Hybridisation was carried out in a mixture containing formamide $50 \% \mathrm{v} / \mathrm{v}, 5 \times \operatorname{SSPE}(1 \times \mathrm{SSPE}, \mathrm{pH} 7 \cdot 4$, is $0.18 \mathrm{~mm} \mathrm{NaCl}, 10 \mathrm{~mm} \mathrm{NaH} \mathrm{PO}_{4}$ and $1 \mathrm{mM}$ EDTA) and $0.1 \%$ each of Ficoll (mol.wt 400000 ), polyvinylpyrrolidone, bovine serum albumin and SDS, $0.01 \mathrm{M}$ dithiothreitol and $100 \mu \mathrm{g}$ denatured salmon sperm DNA $/ \mathrm{ml}$. After washing for $2 \mathrm{~h}$ in $50 \mathrm{~mm}$ Tris- $\mathrm{HCl}$ (pH 8.0) containing $1 \mathrm{M} \mathrm{NaCl}, 1 \mathrm{~mm}$ EDTA and SDS $0 \cdot 1 \%$, nylon filters were incubated for $4 \mathrm{~h}$ at $42^{\circ} \mathrm{C}$ in hybridisation solution without labelled probe. They were then transferred to fresh hybridisation solution containing $10^{6}-10^{7} \mathrm{cpm}$ heat-denatured probe DNA and incubated overnight at $42^{\circ} \mathrm{C}$. The filters were then washed in: (i) four changes (10 min each) of $2 \times \mathrm{SSC}$ containing SDS $0 \cdot 1 \%$ at room temperature $(1 \times \mathrm{SSC}$ is

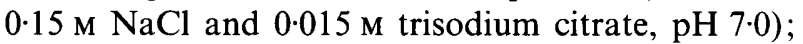
(ii) $1 \times \mathrm{SSC}$ containing SDS $0.1 \%$ at $68^{\circ} \mathrm{C}$ for $2 \mathrm{~h}$; (iii) $0.2 \times \mathrm{SSC}$ containing SDS $0.1 \%$ for $1 \mathrm{~h}$ at $68^{\circ} \mathrm{C}$. The filters were allowed to dry at room temperature and were then exposed to X-ray film.

\section{Results}

All six strains of Aeromonas spp. showed mannoseresistant diffuse adhesion to Caco-2 cells (fig. 1A) irrespective of the age of the monolayers, although the adhesion of one strain (no. 21) was less than had been seen with INT407 cells. The adherence of four strains (nos. 62, 106, 107 and 189) was inhibited by the addition of L-fucose to the tissue culture medium (fig. 1B), but was unaffected by the addition of D-galactose. No accumulation of filamentous actin was observed in FAS tests in spite of massive adhesion of aeromonads.

Electronmicroscopy showed that Caco-2 cells produced a well-defined brush border with microvilli at their apical surfaces (figs. 2A and 3A). As expected from the light microscopic studies, each strain showed adherence to Caco-2 cells. After a 1-h multiplication period, the organisms could be seen adhering to intact microvilli. On some cells, there was damage to the brush border and signs of disruption and irregularities 

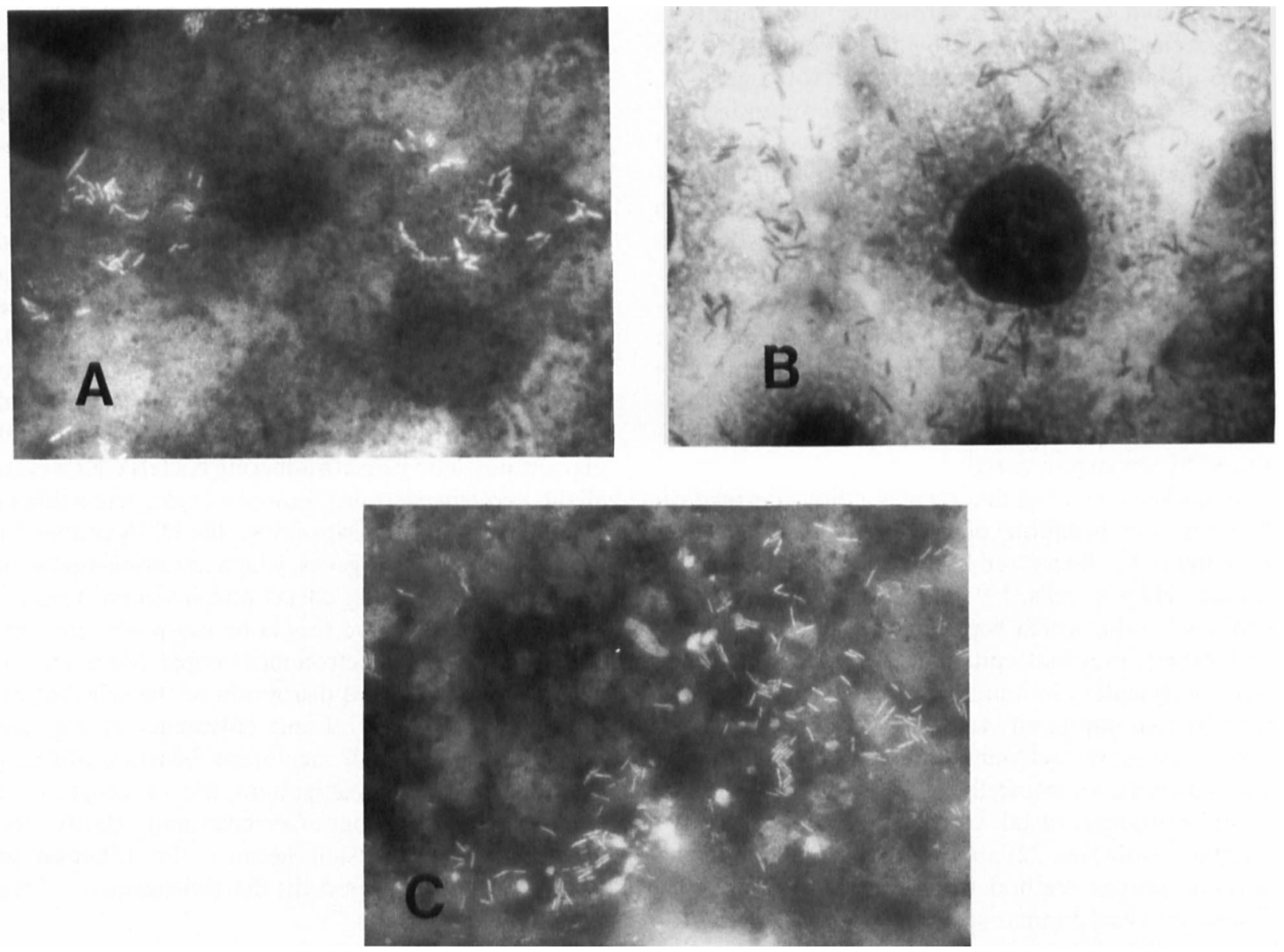

Fig. 4. Acridine orange-crystal violet staining of Caco-2 cells, A, fluorescent intracellular organisms of enteroinvasive $E$. coli E35990; B, A. hydrophila (strain no. 62) showing no fluorescent bacteria in 5-day-old culture of Caco-2 cells; $\mathbf{C}$, numbers of fluorescent aeromonads (strain no. 62) in 14-day-old culture of Caco-2 cells. $(\times 575)$.

in the distribution of microvilli were observed (figs. 2B and $\mathrm{C}$ ). After a 2-h multiplication period, extensive adhesion was observed (fig. 3B). As the infection continued $(2-3 \mathrm{~h})$, disruption of the cells became more apparent (fig. 3C), and the cells detached from the support. Some aeromonads (strain nos. 62 and 106) were found in membrane-bound inclusions within Caco-2 cells (fig. 3D). Occasionally, the membrane of the vacuole was difficult to discern; therefore, it was not clear whether these aeromonads always remained within membrane-bound vacuoles after invasion.

Intracellular fluorescent enteroinvasive $E$. coli were clearly seen by the acridine orange-crystal violet staining method (fig. 4A). Although no fluorescent aeromonads were observed in experiments with 5-dayold cultures of Caco- 2 cells by the acridine orange method (fig. 4B), three strains of Aeromonas spp. (nos. 22,62 and 106) showed numbers of fluorescent bacteria in 14-day-old cultures of Caco-2 cells (fig. 4C).

None of the Aeromonas strains showed positive reactions in hybridisation tests with the eae or ipa $\mathrm{B}$ probes.

\section{Discussion}

Adhesion of bacteria to mucosal surfaces has been recognised as an important process in the pathogenesis of most infections in man and animals. We had previously found that aeromonads which showed mannose-resistant adhesion to INT407 cells were present at significantly higher levels among strains isolated from faecal specimens than among strains isolated from samples of food or river water ${ }^{14}$ Current experiments revealed that Aeromonas strains that had shown mannose-resistant adhesion to INT407 cells were also able to adhere to Caco-2 cells in a mannoseresistant manner. Furthermore, it appeared that some Aeromonas strains could be invasive for Caco-2 cells. Morris et al. showed that adherence and invasion of non-O1 V. cholerae strains to Caco-2 cells correlated with human and rabbit enteropathogenicity. ${ }^{22,29.30}$ Although diarrhoeagenicity for man or rabbits of the Aeromonas strains used in our study remains to be confirmed, the adhesion to and invasion of Caco-2 cells was as extensive as that of non-O1 V. cholerae. This, combined with the observation that these adhesive aeromonads were detected more frequently in faecal specimens than environmental specimens, ${ }^{14}$ suggests that these organisms are enteropathogenic.

Previously we observed the presence of a few supple and curvilinear fimbriae on two strains (nos. 106 and 189). ${ }^{14}$ However, it seems unlikely that fimbriae played an important role in Caco-2 cell adhesion. Fimbrialike structures were not observed between the aero- 
monads and Caco- 2 cells. Moreover, the organisms were seen close to the microvilli, in contrast to the more distant adherence given by enterotoxigenic $E$. coli possessing fimbrial colonisation factor antigens. ${ }^{31}$ A non-O1 $V$. cholerae strain that was Caco-2 adhesive and diarrhoeagenic in human volunteer studies did not produce fimbriae. ${ }^{22}$ Non-fimbrial adhesive factors such as outer-membrane proteins might be involved in the adhesion. ${ }^{32,33}$ Fucose inhibited the adhesion of four strains (nos. 62, 106, 107 and 189) to both Caco2 cells and INT407 cells, suggesting that receptors on the cell surfaces may involve this carbohydrate. By contrast, two other strains may recognise other substances as receptors because their adhesion was unaffected by the sugars tested.

It has been reported that there is a direct correlation between the isolation of Aeromonas strains from dysentery-like illness and the ability of the strains to invade HEp-2 cells. $^{34,35}$ However, a non-O1 $V$. cholerae strain, which was invasive to $\mathrm{Caco}-2$ cells $^{22}$ and rabbit intestinal epithelium, ${ }^{30}$ caused diarrhoea but not dysentery in human volunteers. ${ }^{29}$ Invasion of cells by two strains of Aeromonas spp. (nos. 62 and 106) was seen by electronmicroscopy, and these strains also appeared as intracellular fluorescent bacteria in acridine orange-crystal violet staining experiments. Another strain (no. 22) appeared to be invasive by the acridine orange method but this could not be confirmed by electronmicroscopy. Although the enteroinvasive $E$. coli strain could be detected by acridine orange-crystal violet staining to be within Caco-2 cells irrespective of their age, the invasive strains of Aero-

\section{References}

1. Cahill MM. Virulence factors in motile Aeromonas species. $J$ Appl Bacteriol 1990; 69: 1-16.

2. Holmberg SD, Farmer JJ. Aeromonas hydrophila and Plesiomonas shigelloides as causes of intestinal infections. Rev Infect Dis 1984; 6: 633-639.

3. Janda JM. Recent advances in the study of the taxonomy, pathogenicity, and infectious syndromes associated with the genus Aeromonas. Clin Microbiol Rev 1991: 4: 397-410.

4. Callister SM, Agger WA. Enumeration and characterization of Aeromonas hydrophila and Aeromonas caviae isolated from grocery store produce. Appl Environ Microbiol 1987; 53: 249-253.

5. Nishikawa $Y$, Kishi $T$. Isolation and characterization of motile Aeromonas from human, food and environmental specimens. Epidemiol Infect 1988; 101: 213-223.

6. Palumbo SA, Maxino F, Williams AC, Buchanan RL, Thayer DW. Starch-ampicillin agar for the quantitative detection of Aeromonas hydrophila. Appl Environ Microbiol 1985; 50 1027-1030.

7. Law D. Virulence factors of enteropathogenic Escherichia coli. $J$ Med Microbiol 1988; 26: 1-10.

8. Levine MM. Escherichia coli that cause diarrhea: enterotoxigenic, enteropathogenic, enteroinvasive, enterohemorrhagic, and enteroadherent. $J$ Infect Dis 1987; 155: 377-389.

9. Asao T, Kozaki S, Kato K et al. Purification and characterization of an Aeromonas hydrophila hemolysin. $J$ Clin Microbiol 1986; 24: 228-232

10. Stelma GN, Johnson $\mathrm{CH}$, Spaulding P. Evidence for the direct involvement of $\beta$-hemolysin in Aeromonas hydrophila enteropathogenicity. Curr Microbiol 1986; 14: 71-77. monas spp. were not seen within 5-day-old monolayers of Caco-2 cells. The limited invasive ability of Aeromonas strains observed in our current experiments suggests that their invasive mechanism may differ from that of enteroinvasive E. coli or Shigella organisms.

Enteropathogenic $E$.coli and enterohaemorrhagic $E$. coli cause loss of intestinal epithelial cell microvilli and adhere to the cell membrane intimately: the bacteria are partially surrounded by cup-like projections of the apical enterocyte membrane. Knutton et al..$^{25}$ developed the fluorescence actin staining (FAS) assay to screen bacteria for the ability to cause attaching and effacing lesions which is based upon the formation of filamentous actin beneath adhering bacteria. However, all the Aeromonas strains showed a negative reaction in FAS tests and hybridisation with the DNA probes for the $E$ coli eae or ipaB genes, which are associated with attaching and effacing effects and invasion, respectively. ${ }^{23,24}$ The negative results by eae-probe are concordant with our electronmicroscopic observations, since the latter showed disruption of the cells but no dense concentrations of microfilaments or cup-like projections of the cell membrane beneath adhering bacteria. Further investigations are in progress to confirm the enteropathogenicity and clarify the mechanisms of adhesion because the adhesion to Caco- 2 cells does support the diarrhoeagenicity of the Aeromonas organisms.

The assistance of Ms B. Said in the culture of cells, Dr G. A Willshaw and $\mathrm{Mr} \mathrm{B}$. Jiggle in DNA probe tests, and $\mathrm{Mr} \mathrm{T}$. Cheasty in identification of Aeromonas spp. is greatly appreciated.

11. Morgan DR, Johnson PC, DuPont HL, Satterwhite TK, Wood LV. Lack of correlation between known virulence properties of Aeromonas hydrophila and enteropathogenicity for humans. Infect Immun 1985; 50: 62-65.

12. Freter R. Association of enteropathogenic bacteria with the mucosa of the small intestine: mechanisms and pathogenic implications. In: Ouchterlony O, Holmgren J, Craig J, Barua D (eds) Cholera and related diarrheas. Basel, Karger, 1978: 155-170.

13. Sattherwhite TK, Evans DG, DuPont HL, Evans DJ. Role of Escherichia coli colonisation factor antigen in acute diarrhoea. Lancet 1978; 2: 181-184.

14. Nishikawa Y, Kimura T, Kishi T. Mannose-resistant adhesion of motile Aeromonas to INT407 cells and the differences among isolates from humans, food and water. Epidemiol Infect 1991; 107: 171-179.

15. Pinto M, Robine-Leon S, Appay MD et al. Enterocyte-like differentiation and polarization of the human colon carcinoma cell line Caco-2 in culture. Biol Cell $1983 ; 47$ 323-330.

16. Darfeuille-Michaud A, Aubel D, Chauvière G et al. Adhesion of enterotoxigenic Escherichia coli to the human colon carcinoma cell line Caco-2 in culture. Infect Immun 1990 58: 893-902.

17. Everest PH, Goossens H, Butzler J-P et al. Differentiated Caco2 cells as a model for enteric invasion by Campylobacter jejuni and C. coli. J Med Microbiol 1992; 37: 319-325.

18. Finlay BB, Falkow S. Salmonella interactions with polarized human intestinal Caco-2 epithelial cells. J Infect Dis 1990 162: 1096-1106.

19. Kerneis S, Bilge SS, Fourel V, Chauvière G, Coconnier M-H Servin AL. Use of purified F1 845 fimbrial adhesin to study localization and expression of receptors for diffusely 
adhering Escherichia coli during enterocytic differentiation of human colon carcinoma cell lines HT-29 and Caco-2 in culture. Infect Immun 1991; 59: 4013-4018.

20. Mounier J, Vasselon T, Hellio R, Lesourd M, Sansonetti PJ Shigella flexneri enters human colonic Caco-2 epithelial cells through the basolateral pole. Infect Immun 1992; 60: 237-248.

21. Rigothier MC, Coconnier MH, Servin AL, Gayral P. A new in vitro model of Entamoeba histolytica adhesion, using the human colon carcinoma cell line Caco-2: scanning electron microscopic study. Infect Immun 1991; 59: 4142-4146.

22. Panigrahi $P$, Tall BD, Russell RG, Detolla LJ, Morris JG. Development of an in vitro model for study of non-O1 Vibrio cholerae virulence using Caco-2 cells. Infect Immun 1990; 58: 3415-3424.

23. Jerse AE, Yu J, Tall BD, Kaper JB. A genetic locus of enteropathogenic Escherichia coli necessary for the production of attaching and effacing lesions on tissue culture cells. Proc Natl Acad Sci USA 1990; 87: 7839-7843.

24. Baudry B, Maurelli AT, Clerc P, Sadoff JC, Sansonetti PJ. Localization of plasmid loci necessary for the entry of Shigella flexneri into HeLa cells, and characterization of one locus encoding four immunogenic polypeptides. J Gen Microbiol 1987; 133: 3403-3413

25. Knutton S, Baldwin T, Williams PH, McNeish AS. Actin accumulation at sites of bacterial adhesion to tissue culture cells: basis of a new diagnostic test for enteropathogenic and enterohemorrhagic Escherichia coli. Infect Immun 1989; 57: 1290-1298.

26. Miliotis MD. Acridine orange stain for determining intracellular enteropathogens in HeLa cells. $J$ Clin Microbiol $1991 ; 29: 830-831$.
27. Feinberg AP, Vogelstein B. A technique for radiolabeling DNA restriction endonuclease fragments to high specific activity. Anal Biochem 1983; 132: 6-13.

28. Maniatis T, Fritsch EF, Sambrook J (eds). Molecular cloning: a laboratory manual. New York, Cold Spring Harbor Laboratory. 1982.

29. Morris JG, Takeda T, Tall BD et al. Experimental non-O group 1 Vibrio cholerae gastroenteritis in humans. $J$ Clin Invest 1990; 85: 697-705.

30. Russell RG, Tall BD, Morris JG. Non-O1 Vibrio cholerae intestinal pathology and invasion in the removable intestinal tie adult rabbit diarrhea model. Infect Immun 1992; 60: $435-442$.

31. Knutton S, Lloyd DR, McNeish AS. Identification of a new fimbrial structure in enterotoxigenic Escherichia coli (ETEC) serotype O148:H28 which adheres to human intestinal mucosa: a potentially new human ETEC colonization factor. Infect Immun 1987; 55: 86-92.

32. Chart H, Scotland SM, Willshaw GA, Rowe B. HEp-2 adhesion and the expression of a $94 \mathrm{KDa}$ outer-membrane protein by strains of Escherichia coli belonging to enteropathogenic serogroups. J Gen Microbiol 1988; 134: 1315-1321.

33. Owen P. Outer membrane proteins: their role in virulence. In: Owen P, Foster TJ (eds) Immunochemical and molecular genetic analysis of bacterial pathogens. Amsterdam, Elsevier. 1988: 33-37.

34. Lawson MA, Burke V, Chang BJ. Invasion of HEp-2 cells by fecal isolates of Aeromonas hydrophila. Infect Immun 1985; 47: $680-683$.

35. Watson IM, Robinson JO, Burke V, Gracey M. Invasiveness of Aeromonas spp. in relation to biotype, virulence factors, and clinical features. J Clin Microbiol 1985; 22: 48-51. 